\title{
Opinions of Physical Education Teachers on the Concept of Sportsmanship
}

\author{
Yakup Koç $^{1} \&$ Oğuz Kaan Esentürk ${ }^{2}$ \\ ${ }^{1}$ Faculty of Education, Erzincan University, Erzincan, Turkey \\ ${ }^{2}$ Faculty of Sport Sciences, Gazi University, Ankara, Turkey \\ Correspondence: Yakup Koç, Faculty of Education, Erzincan University, Erzincan, Turkey. E-mail: \\ ykoc79@gmail.com
}

Received: September 7, 2017

Accepted: September 19, 2017 Online Published: September 21, 2017

doi:10.5539/jel.v7n1p71

URL: https://doi.org/10.5539/jel.v7n1p71

\begin{abstract}
The purpose of this study is to evaluate the opinions of physical education teachers on the concept of sportsmanship. This study, which has been based on the qualitative research paradigm, involves opinions of 13 physical education teachers ( 9 males and 4 females) which serve in public schools of Turkey and which have been specified through a critical incident sampling. A "semi-structured interview form" which has been developed using a literature review and expert opinions has been used to collect data. The descriptive analysis technique was used in analyzing the obtained data. Results of the study showed that physical education teachers have different views on the sportsmanship concept. Although physical education teachers stated their opinions on requirement of activities towards enhancing the awareness with regard to the sportsmanship concept in schools they work in, it was determined that they performed few activities pertaining to sportsmanship. However, it was seen that the current physical education course programs do not provide teachers with sufficient information regarding the sportsmanship education and that teachers desire to have education on the sportsmanship concept during in-service training activities. Furthermore, the involved teachers think that quality of the current university education in terms of the sportsmanship concept should be improved. In conclusion, in order to enhance the quality of physical education teachers with regard to the sportsmanship concept, particularly faculties of education are recommended to include compulsory courses containing both the theory and practice on sportsmanship and researchers are recommended to develop sample activities and practice guiding physical education teachers.
\end{abstract}

Keywords: physical education teacher, sportsmanship, physical education and sports course

\section{Introduction}

Character development has been one of the important goals of organized sports since 1920's and 1930's. For instance, Little League Baseball, which has been found in 1939, was designed "to create superior citizens rather than superior athletes" (Chudacoff, 2007). Although character development is priorily one of the important goals of youth sports organizations, it is also perceived as a means of solution against bad behaviors in school sports (Clifford \& Feezel, 1997; Lumpkin, Stoll, \& Beller, 2002; Martens, 2004; Power \& Sheehan, 2014; Thompson, 1995). In some states of the United States of America, character development course programs are mandatory, required by law, in schools. Sportsmanship is one of these programs (www.character.org, 2016). Shields and Bredemeier (1995) defines sportsmanship as the virtue of regulating the competitive motivation of the game based on moral goals. Sportsmanship involves attributes such as integrity, patience, self-control, fairness, forgiveness, generosity and politeness (Keating, 2007). Sportsmanship and Fair play are used in the same meaning (Keating, 2007). In Turkey, predominantly in academic environments, "gentlemanship in sports (sporda centilmenlik)" is a term which corresponds to the same meaning (Koç, 2017; Pehlivan, 2004).

Problems pertaining to lack of sportsmanship, fair play, aggresion and violence in sports environments have been evaluated by many researchers in their studies (Yıldıran, 2005; Yapan, 2007; Pehlivan, 2004). Individuals who were the source of these problems were presented physical education and sports courses under the scope of systematic programs in schools. Consequently, despite physical education and sports courses being used as a means of physical development and muscle development fundemantally, in recent years the importance of sports on emotional, spiritual, psycho-motor and physical developments are evaluated (Demirhan et al., 2002). It is 
hypothesized that teaching the principles of virtues to students through courses in their school years would resolve many problems fundamentally (Aydın \& Gürler, 2014). Positive effects of sportsmanship on children and young athletes have been displayed as the results of many experimental studies (Arthur-Banning, Paisley, \& Wells, 2007; Blair, 2014; Cecchini, Montero, Alonso, Izquierdo, \& Contreras, 2007; Hassandra, Goudas, Hatzigeorgiadis, \& Theodorakis, 2007; Lodl, 2005; Wells, Ellis, Paisley, \& Arthur-Banning, 2005; Wells, Arthur-Banning, Paisley, Ellis Roark, \& Fisher, 2008). In addition, many other studies also displayed that behavior of students remain undeveloped in case physical education course lacks content towards developing social behavior of children (Giebink \& McKenzie, 1985; Hellison, 2003; Patrick, Ward, \& Crouch, 1998; Siedentop, Hastie, \& van der Mars, 2004). On the other hand, Dick and Carey (1996) specified that education is a systematic process and all components of education (e.g., teacher, student, environment and material) have critical role for successful learning. In his experimental research, Hansen (1999) displayed that cognitive sportsmanship training programs contributed to improvement of sportsmanship on teachers. 2 different protocols were used in the study and contributions of these protocols were observed. Under the scope of a domestic project supported by EU funds in Portugal, a guide book named "Ethics in sport guidelines for teachers" was prepared to improve ethics of sports teachers. Applications and characteristics of good physical education teachers were being told in the book (Rosa, 2015).

The most prominent opinion on aggression, violence and sportsmanship is the social learning model of Bandura. Consequently, the results of a study which evaluated the effects of participation in sports on aggression, violence and sportsmanship displayed various results and such variety was explained by the effect of different social environments on same settings. In this context, participation in sports can support and teach both aggression and sportsmanship (Nucci \& Young-Shim, 2005). Physical education and sports teachers are responsible for serving as a role model and facilitating a peaceful social environment in the school as the authorized person. Shields and Bredemeier (1995) hypothesized that physical education classes were the best environment for teaching social morals.

Cours content of college programs in Turkey either has limited information or none in terms of sportsmanship. In addition to that, curriculum programs approved and released by National Ministry of Education also lack explanatory information and examples related to the subject. However, for other course programs, instructor coordinates many activities and exercises on the subject material. However, teachers lack exhibits and exercises on the concept of sportsmanship which is a very important subject for physical education classes. For that reason, putting the blame on physical education instructors for being insufficient would be an unjust claim. Consequently, Yildiran (2005) underlined that the inadequate undergraduate program would not be sufficient based on the same reasons. In USA, there are application guide books for physical teachers in high schools (www.northropbruins.org; www.hb.edu). These guide books includes ethic and behavioral codes supplementing all other behaviors expected by high school sports courses for all individuals. The application guide book of physical education and sports classes for grades 5-8 in Turkey includes only one example activity for a single subject (MEB, 2013). At this point, the question of "What are the trainings, opinions, applications and suggestions of physical education teachers currently instructing in schools and graduated from different universities at different dates?" is brought up. This study aims to respond to this question. The purpose of this study is to evaluate the opinions of physical education teachers on the concept of sportsmanship.

\section{Method}

This section includes information related to model, study group, data collection tools and data analysis.

\subsection{Model of the Study}

In this research, qualitative research method focusing on structured reality, close relationship between the researcher and the subject or group, how the concepts and experience emerged and how to attribute a meaning to those was used (Denzin \& Lincoln, 2000).

\subsection{Study Group}

13 physical education teachers ( 9 male, 4 female) who worked in schools operating under the National Ministry of Education in Turkey in 2015-2016 school year. All 13 participants graduated from 11 different undergraduate faculties and the average age of participants is 32.38. Work experience of participants varies between 2 to 17 years and average work experience is 9.23 years.

Critical incident sampling method was used for determining the study group. Due to the fact that critical incident sampling includes chosen environment and characteristics of the group or individuals, it could reflect a holistic perspective on the subject matter (Collins, Onwuegbuzie, \& Jiao, 2007). 2 critical cases were considered during 
the selection of participants. First case is the date of graduation from their undergraduate schools. The purpose of this selection depends on the fundamental changes on the curriculum in 1998 and in 2007. For that reason, participants were divided into 3 groups (1) Group = Graduated before 2002, 2) Group = Graduated between 2002 and 2010,3) Group = Graduated after 2010). Second case is that participants needed to graduate from different universities. The purpose of this selection depends on the fact that participants earned different knowledge and skills on sportsmanship in programs of different universities.

\subsection{Data Collection Tools}

In this research, semi structured interview form of Bogdan and Biklen (2007) which allows the participants to express their opinions freely on a specific subject was used. In determining the questions of these forms, priorly literature related to the subject was reviewed (Güven, 2009; Martens, 2004; Pehlivan, 2004; Yapan, 2007; Yildiran, 2005) for the purpose of revealing the perception of teachers working in different high schools, then 20 questions (and sub-questions) towards general quality were designated. In addition, academic publications served as a foundation on the problems related to the field. Prepared general questions were sent to 3 different physical education teachers with different years of work experience for the purpose of pre-interviewing in order to validate the clarity and comprehensibility of the questions in addition to clarifying the valid perception of physical education teachers on the concept of sportsmanship. As a result of the validity of scope conducted by experts, the form consisting of 20 questions was then transformed to the final form consisting of 16 questions (questions and sub-questions) on 6 topics.

\subsection{Analysis of the Data}

Descriptive analysis was used in the research. Descriptive analysis is shallow when compared to content analysis and is more frequently used in researches in which conceptual structure of the research is pre-determined (Yıldırım \& Şimşek, 2013). In this analysis process, participants are given code names. These code names helped supporting participant opinions and themes. Later, minutes of the interviews with participants were enscribed. Then, these inscriptions were presented to the participants for verification purposes and missing/misunderstood information were being corrected, if any, and then mutual opinions and frequencies of different participants were determined and required encoding is performed. These code names were, respectively, initial letter of the names, genders and graduation date groups of participants. For instance TM1 = [T(Tunç).M(Male).1(Graduated before 2002)].

\section{Results}

16 questions asked to participants (PF1, AF3, EF2, IF3, ZM1, MM2, TM1, RM1, OM2, YM1, SM2, BM3, VM3) are evaluated under 6 topics. Opinions and sample testimonies provided by participants on these questions are listed under this section.

\subsection{What Are Your Sources of Information for the Concept of Sportsmanship?}

Majority of the participants stated that they did not receive any training programs on sportsmanship in college and that they did not have sufficient information. Only 2 of the participants (MM2, AF3) attended a course on sportsmanship during their undergraduate program. These 2 participants who attended such course stated that these courses were only on theory and there were no activities related to application. Some of other participants (TM1, ZM1, OM2, YM1, SM2) stated that instructors talked about or noticed the class on the applications of the subject of sportsmanship in some undergraduate courses. In addition, some participants stated that they received information on sportsmanship through different sources such as internet (AF3) or books (YM1). Sample testimonies of the participants goes as follows: ME2: "Our instructor used to assign a homework on fair play. But this was only on theory. There were no applications. We were only provided with information.", AF3: "I took an elective course and it was theoretical. There were very few of us since it was an elective course. The course was more liked conversational. Outside the course, I was searching the web for some information. You must stress the importance of fair play and sportsmanship especially in case of bad weather conditions (Since it has not a indoor sports hall, it done in the classroom) and I was searching sample cases from the internet before the course hours.", and YM1 stated that "I learned that the loving fraternity environment which feeds the concept of olympism, which contributes to the soul of olympics, was called fair play in recent times and this I learned from a book I read.".

\subsection{What Is Your Opinion on the Concept of Sportsmanship?}

Analyzing the initial opinion of physical education teachers on the concept of sportsmanship, the first thing that came to their mind was "gentlemanship" (YF3, EF3, YM1, RM1, TM1, OM2, SM2, MM2), "admiring the winner and accepting the loss" (ZM1, RM1, PF3, IF3), "making right decisions under tough conditions and 
being fair and just" (EF2, MM2), "not using illegal methods for winning" (RM1), "not being selfish" (AF3), "enjoying what one does" (TM1), "not doing on others what is not liked by us" (RM1), "being tolerance" (IF3).

Participants evaluated the concept of sportsmanship on different aspects. Participants also stated that the concept of sportsmanship was interconnected with many different factors. In addition to this, some of the participants underlined the importance of moral (YM1, IF3, ZM1), cultural (TM1), religious (SM2) or familial (OM2, VM3) contents of the concept of sportsmanship were more important.

For example; RM1 stated that "I think religious, moral and educational aspects are all rings of the chain. For example, last week our subject topic was olympism and we told the students that sports must be conducted in a friendly and fraternity environment then we observe that students also pay attention to this concept in other parts of their education. If the child is raised in good manners in terms of his character and morals, this understanding improves in time, which makes our job easier and its effects permanent", and YM1 stated that "moral values are important. If a student is taught about the concept of values during his elementary school and junior high school years, his sportsmanship will be inevitably displayed in the upcoming years. How can you tell a student about sportsmanship if he lacks the concepts of values and virtues? Your efforts will be in vain even if you tell him". TM1 stated that "sportsmanship is in positive correlaiton with culture", and SM2 stated that "For me, there is also religious aspect of sportsmanship. Since it is our mind which guides us on which choices are correct and which are wrong, we have to reflect the same approach on the sports field." and VM3 stated that "students coming from the same families always display same behaviors.".

\subsection{What Is Your Opinion on Sportsmanship Behavior of Teachers?}

All participants stressed out the importance of teachers serving as a role model. On this subject, VM3 stated that "if we become good models for them as teachers and seriously display this model, I definitely believe that these behaviors will become permanent". IF3 stated on the same subject that "I think trainers and students display the same behavior displayed by teachers and athletes and for that reason, teachers have great responsibility as role models". ZM1's testimony on the same subject was that "behaviors of physical education teachers matter more than their words, if the teacher is unable to apply in a football match what he instructed in the course, this is observed by students, because students are very good at observing. Pay attention to how you behave against the referee, if you tell the students to be respectful against the referee and you löse control in the match, it turns out the same as a heavy smoker's advice to a young person not to smoke". However, some of the participants (EF2, RM1, YM1) confessed that they were failing to serve as a good role model. In addition, participants stated that physical education teachers display unsportsmanship behaviors such as psychological pressure and insult on failing students (YM1), enrolling non-students in school matches (MM2), not accepting loss (IF3), encouraging students to perform fouls (VM3) and objections or insults on referees (VM3, MM2). Parallel to their insufficient knowledge on the subject matter, participants were failing to report many examples of good conduct in accordance with sportsmanship. Examples provided by participants were minor incidents such as "not being angry to a student which performed a harsh tackles to teacher" (VM3) or "congratulating the winning side in school matches" (IF3).

\subsection{What Is Your Opinion on Sportsmanship Behavior of Students?}

Participants stated that they observed various incidents related to sportsmanship behavior of students in course hours. Among these behaviors, examples of negative ones include "Not being able to accept loss and yelling" (SM2), "upsetting teammates in case of failing action" (ZM1), "laughing at overweight students while performing actions" (MM2), "pushing each other" (AF3, EF3), "performing fouls in critical positions" (AF3, IF3), "sending the ball outside the field to pass time" (AF3), "violence against the opponent" (BM3), "foul language and swearing against the opponent" (IF3). Negative behaviors were generally been given verbal warning by teachers but sometimes teachers applied certain punishments such as "expelling the student from the game" (AF3), "banning the students from school matches" (IF3). Although general opinion is that punishments lead to only short-term benefits, some of the participants (BM3, RM1) stated that other factors such as family and environment were limiting the long-term effects of punishments.

Reviewing positive behavior examples, "helping a player to stand up" (AF3, PF1, BM3), "saying sorry to a friend after hitting him while running" (MM2), "helping a teammate stand up" (IF3), "correcting the wrong decision of the referee" (VM3), "supporting and encouraging friends who fail at exercises" (AF3) were stated by teachers. It is also understood that such behavior was encouraged verbally by teachers. IF3 stated that "I provide verbal feedback. We say well done, what a beautiful behavior it was". In addition, a participant gives prizes for fair play (SM2). Those feedbacks create chain reaction among students and contribute to increase of positive behavior. Pertaining to positive effects of feedback on students, IF3 stated that "In their age group, even a small 
well done is received well by them. And if you say well done to him in a crowded environment, let's say in front of his friends, other students are also enticed to receive a well done".

\subsection{Can You Provide Us Some Information on Sportsmanship Education Applications You Provided?}

It was observed that physical education teachers enforced few activities on sportsmanship. Participants stated that they did not have any idea on what kind of method they should follow in order to increase sportsmanship behavior. Participants stated that they had a more reactive approach during the course hours and generally intervened in cases of negative conduct. In addition, although very few in count, some participants enforced some activities related to sportsmanship such as providing information on the concept of sportsmanship (SM2), assigning homeworks related to sportsmanship (BM3), holding debate sessions on actual topics of sportsmanship (AF3, RM1, SM2), holding debate sessions on negative conduct (MM2), making sure the losing side applauds the winning side (ZM1, TM1, PF1).

\subsection{What Are Your Suggestions for Improving Sportsmanship Behavior in Physical Education and Sports Courses?}

There is a consensus on promoting activities in schools which would increase the awareness of physical education teachers on the concept of sportsmanship. Participants also stated that despite the fact that course programs in elementary schools and junior high schools have enough learning outcomes in terms of sportsmanship; there were only limited number of sample activities and applications to guide teachers. Participants stated the following in terms of activities in schools that would contribute to improvement of sportsmanship: "Demonstrative visual materials such as compositions and poems, presentations on posters and bulletin boards" (ZM1), "sportsmanship prize/fair play prize" (TM1, ZM1, MM2), "examples of recent news and sports activities" (MM2), "application of drama activities related to sportsmanship" (MM2), "fair play festival during spring term" (MM2, RM1), "family education" (BM3), "providing theoretical information at the beginning of subject topic" (EF2, SM2), "giving talks on sports ethics at the beginning of each course" (SM2, VM3), "including sportsmanship to education on values" (PF1), "bringing to the class short-films on sportsmanship" (BM3), "preparing a guide on sportsmanship for students" (IF3).

There is consensus on the fact that 5 th grade (this is the grade that students start being tutored by physical education teachers) would be the best for sportsmanship applications which would be implemented under the scope of a planned program. In addition to that, teachers underlined that earlier the concept of sportsmanship is implemented in the curriculum, better the effects will be. In addition, all participants agreed that programs scheduled in schools might contribute to reduction of violence and unsporting behavior in sports fields. On this matter, ZM1 stated that "we have to start from the individual if we desire to eliminate violence from sports. We constantly provide examples during course hours. In different countries, supporters of different teams can dine together after a match. Why are we still unable to eliminate the use of foul language in our stadiums?".

It was also observed that participants desire to receive in-service training on the concept of sportsmanship. However, participants stated that schools should focus on application in addition to theoretical knowledge. In addition to all these findings, it was also observed that scope and quality of the education provided on the concept of sportsmanship in undergraduate programs must be improved. At this point, most of the participants stated that sportsmanship should be included as a course, either elective or must, whereas TM1 stated that sportsmanship can be included as content in theoretical or applied courses.

\section{Discussion and Conclusion}

This section includes results and suggestions by discussing results of studies on the fields and opinions of physical education teachers, who graduated from different universities, have differed professional experience and service time and serve in public shools.

It was observed that participants did not receive training on the concept of sportsmanship neither during their undergraduate program nor during their service. Güven (2009) claimed that undergraduate programs producing physical education teachers should include courses on sportive virtue, sport ethics and sportsmanship and that it would be meaningless to expect fair conduct otherwise. Yildiran (2005) drew the attention of officials on insufficiency of undergraduate program contents. However, the need of fair conduct in sports in Turkey in recent years caused new initiatives to be taken in universities. For instance, establishment of a social club on sportsmanship in Selçuk University and inclusion of the "Fair Play" course in the undergraduate program might be given as examples. This activity earned the Fair Play Prize in 2015. In addition to that, a project on increasing awareness in terms of Fair Play launched by the National Olympics Committee is also a good example (Arıpınar 
\& Donuk, 2017). It is obvious that such activities should be held more frequently by universities and National Ministry of Education.

It was observed that participants were able to define the concept of sportsmanship theoretically. It was a notable result that the first thing came to the minds of participants was gentlemanship $(n=8,62 \%)$ on the concept of sportsmanship. It was also understood that participants preferred using the term "gentlemanship" rather than sportsmanship. Consequently, in addition to terms of fair play and sportsmanship; use of the term "gentlemanship" is more prevalent in the education sector (Çağlayan \& Gül, 2017). First things that came to the minds participants was respect for the competitor, abiding to rules (Vallerand, Blanchard, \& Provencher, 1997; Koç \& Yeniçeri, 2017), appreciating the winner, accepting to lose (Green \& Gabbard, 1999) and making right decisions under tough conditions (Yıldiran, 2005) which are in accordance with specific definitions on the concept of sportsmanship in the literature. In addition, participants also stated that sportsmanship was in relation with many factors including ethical, cultural and religious factors. Pehlivan (2004) stated that sportsmanship should be evaluated not only as a concept which defines sportive relationships but also as a cultural concept.

Koç and Karabudak (2017) found meaningful correlation between sportsmanship and success in religious ethics course $(r=0.12, p>0.01)$. Only reasonable doubt pertaining to this study is that defining sportsmanship using a single factor would be insufficient. However, the concept of sportsmanship, which is yet an abstract concept in our minds, should be evaluated in a more detailed manner. Despite the fact that number of international researches are increasing in the last 30 years, underlying reasons for fair conduct or unsporting behavior have not been clearly defined yet.

Analyzing the opinions of participants on the role of physical education teachers, participants stressed out the importance of serving as a role model to students. Some participants stated that they failed to serve as a complete role model. According to observations of participants, it is understood that some physical education teachers lose their temper in activities during the courses or in school matches and act like athletes. However, physical education teachers should be more qualified and reflect such qualifications in activities during course hours and help prevent misconduct, violence and unsporting behavior in sports. In their study Hassandra, Bekian and Sakellariou (2007) found that even verbal aggression of physical education teachers can provoke unsporting behavior in students. However, Wolff (1986) claims that personality and behavior of children and young people might be modified if physical education teachers display model behaviors (as cited Pehlivan, 2004, p. 54). At this point, legendary trainer of Notre Dame FC, Knute Rockne's quote summarizes the issue. Knute says "one man practicing good sportsmanship is far better than fifty others preaching it" (as cited Martens, 2004, p. 54). In their study on young football players, Kavussanu and Spray (2006) claimed that physical education teachers play an important role for moral development and that two of the most important duties of these individuals in terms of sports are to condemn and prevent misconduct and to encourage fair conduct. In addition, analyzing foundings on this subject, it is understood that participants gave many examples on misconduct of physical education teachers whereas examples of fair conduct were very limited. This finding alone proves the fact that teachers need support on this subject.

Analyzing the opinions of participants on sportsmanship behavior of students, there were many misconducts and it is understood that reactive approach was taken by teachers rather than preventive classroom method. In class management models of recent years, it is strongly advised not to use reactive model (Demirtaş, 2014), however it is being believed that sportively or socially penalizing misconduct contributes to reduction of misconduct (Bierhoff, 2002). Although few in numbers, fair conduct of students observed by teachers are generally reprimanded with verbal reinforcers. Many researchers believe that reinforcing notable fair conduct with positive feedback and prizes would conribute to increasing the permanency of such behavior (Siedentop et al., 2004; Hassandra, Goudas, Hatzigeorgiadis, \& Theodorakis, 2007). For instance, taking into consideration the psycho-social structures of children and young people, Pehlivan (2004) claimed that awarding fair conduct is an effective means and students should be awarded and put forwards in accordance with such structure. In addition, he also stated that sportsmanship prize should be included in the legislative structure.

Opinions of participants on applications performed by them in physical education and sports courses were evaluated. It is observed that teachers performed few activities pertaining to sportsmanship and in generally did not have any idea on how to implement such activities to their course content. However, some participants stated that they provide theoretical information, discuss recent sports incidents and misconducted behavior and make the losers applaud the winning team. Based on the opinions of teachers, it is understood that they did not know what to do in terms of sportsmanship. This insufficiency is also reflected on their role model behavior. Also Aydoğan (2006) expressed the view that the undergraduate programs for physical education teachers in Turkey 
are inadequate. As stated in the introduction, the experimental research of Hansen (1999) approves that teachers require qualified training programs on sportsmanship. In this context, a guide book was prepared under the scope of a Project funded by the European Union. In USA, there are application guide boks for physical teachers in high schools (www.northropbruins.org; www.hb.edu). These guide books includes ethic and behavioral codes supplementing all other behaviors expected by high school sports courses for all individuals. Koç (2017) claims that one of the most important priority in this respect is that individuals who will teach the concept of sportsmanship to students and athletes to undergo sufficient training.

Analyzing the suggestions of participants for improving sportsmanship behavior of students through physical education and sports classes; it is understood that awarding sportsmanship prizes to students, training families and including sportsmanship to values training are among worthy suggestions. Reviewing the literature, it is understood that activities such as awarding sportsmanship prizes (Bardi \& Schwars, 2013), enforcing drama applications related to sportsmanship (Aydın \& Gürler, 2014; Perry, Clough, \& Crust, 2013), including sportsmanship to the values training (www.character.org, 2016), providing theoretical knowledge at the beginning of the course hour (Koç, 2017a) and preparing bulletin boards/posters related to sportsmanship in class hours (Siedentop et al., 2004) are either actively used or suggested for use.

It is also understood that physical education teachers request sportsmanship programs developed for various age groups to be localized for integration to curriculum program of Turkey and included in the curriculum after 5th grade. Such program has not been developed yet. However, there is an application "Structuring Sportsmanship in Children Games (Küçüklerin Oyununda Centilmenliğin Yapılandırılması-KOCY)" designated by Koç (2017). It is required to determine whether this program is applicable to experimental researches and is effective for improving sportsmanship. In addition, in order to make sure physical education teachers become more qualified in this respect, institutions which train physical education teachers should include must courses which is comprised of both theoretical knowledge and applications and researchers are suggested to develop sample activities and applications which would guide physical education teachers.

As a result, opinions of participants consisting of physical education teachers who graduated from different universities in Turkey and who served in public schools for different time intervals were collected and evaluated using descriptive analysis method. Participants not only stated deficiencies in this field but also provided worthy suggestions. Limitations of this study include the number of work groups, number of questions asked and study being conducted on participants graduating from 11 different universities. In further researches, researchers are suggested to have a broader critical case sample group and use content analysis method which provides opportunity for a more detailed and in-depth analysis.

\section{References}

Arıpınar, E., \& Donuk, B. (2017). Spor yönetim ve organizasyonlarında etik yaklaşımlar Fair play (Beşinci Basım). İstanbul: Ötüken Neşriyat.

Arthur-Banning, S. G., Paisley, K., \& Wells, M. S. (2007). Promoting sportsmanship in youth basketball players: The effect of referees' prosocial behavior techniques. Journal of Park \& Recreation Administration, 25, 96-114.

Aydın, M. Z., \& Gürler, Ş. A. (2014). Okulda değerler eğitimi yöntemler-Etkinlikler-Kaynaklar (4. Basım). Ankara: Nobel Akademi Yayıncılık.

Aydoğan, H. (2006). Beden eğitimi öğretmenlerinin meslekte karşılaş̧tıları sorunlar (Trabzon ili uygulaması) (Unpublished Master Thesis). Gazi University, Ankara, Turkey.

Bardi, A., \& Schwarz, S. H. (2013). How does the value structure underlie value conflict. In J. Whitehead, H. Telfer, \& J. Lambert (Eds.), Values in Youth Sport and Physical Education (pp. 137-151). New York: Routledge.

Bierhoff, H. (2002). Prosocial behaviour. New York: Taylor \& Francis.

Blair, G. T. (2014). The effects of a league gulded sportsmanship program on the behavlors of youth sports athletes (Unpublished master thesis). University of California, Irvine.

Bogdan, R. C., \& Biklen, S. K. (2007). Qualitative research for education. An introduction to theories and method (5th ed.). Boston: Pearson.

Çağlayan, H. S., \& Gül, Ö. (2017). Metaphoric perceptions of the students of the sports sciences faculty regarding the concept of fair-play. Journal of Education and Training Studies, 5(8), 139-150. https://doi.org/10.11114/jets.v5i8.2502 
Cecchini, J. A., Montero, J., Alonso, A., Izquierdo M., \& Contreras, O. (2007). Effects of personal and social responsibility on fair play in sports and self-control in school-aged youths. European Journal of Sport Science, 7(4), 203-211. https://doi.org/10.1080/17461390701718497

Chudacoff, H. P. (2007). Children at play: An American history. New York: York University Press.

Clifford, C., \& Feezell, R. (2010). Sport and character: Reclaiming the principles of sportsmanship. Human Kinetics.

Collins, K. M. T., Onwuegbuzie, A. J., \& Jiao, Q. G. (2007). A mixed methods investigation of mixed methods sampling designs in social and health science research. Journal of Mixed Methods Research, 1, 267-294. https://doi.org/10.1177/1558689807299526

Demirhan, G., Coşkun, H., \& Altay, F. (2002). Beden eğitimi öğretmenlerinin niteliklerine ilişkin görüşleri. Eğitim ve Bilim, 27, 35-41.

Demirtaş, H. (2014). Sınıf yönetiminin temelleri. In H. Kıran (Ed.), Etkili Sınıf Yönetimi (ss. 213-236, 9. Basım). Ankara: Anı Yayıncilık.

Denzin, N. K., \& Yvonna S. L. (2000). Handbook of qualitative research. Thousand Oaks: Sage Publications, Inc.

Dick, W., \& Carey, L. (1996). The systematic design of instruction (4th ed.). New York, NY: Harper Collins.

Giebink, M. P., \& McKenzie, T. L. (1985). Teaching sportsmanship in physical education and recreation: An analysis of interventions and generalization effects. Journal of Teaching in Physical Education, 4, 167-177. https://doi.org/10.1123/jtpe.4.3.167

Green, T., \& Gabbard, C. (1999). Do we need sportsmanship education in secondary school athletics? Physical Educator, 56(2), 98.

Güven, Ö. (2009). Milli beden eğitimi spor politikası ve altıncı spor şurası. Türk Yurdu, 29, 60-65.

Hansen, D. E. (1999). "Fair Play Everyday" A Sportsmanship Training Program For High School Coaches (Published Doctorate thesis). University of Idaho, US.

Hassandra, M., Bekian, A., \& Sakellariou, K. (2007). Physical education teacher's verbal aggression and student's fair play behaviors. Physical Educator, 64(2).

Hassandra, M., Goudas, M., Hatzigeorgiadis, A., \& Theodorakis, Y. (2007). A fair play intervention program in school Olympic education. Eur. J. Psychol. Educ., 22(2), 99-114. https://doi.org/10.1007/BF03173516

Hellison, D. (2003). Teaching responsibility through physical activity (3rd ed.). Champaign, IL: Human Kinetics. http://www.character.org/wp-content/uploads/What-States-Are-Doing.pdf

http://www.northropbruins.org/uploads/2/8/2/3/28238951/northrop_sportsmanship_responsibilities.pdf https://www.hb.edu/uploaded/Athletics/Sportsmanship_for_Coaches.pdf

Kavussanu, M., \& Spray, C. M. (2006). Contextual influences on moral functioning of male youth footballers. The Sport Psychologist, 20, 1-23. https://doi.org/10.1123/tsp.20.1.1

Keating, J. W. (2007). Sportsmanship as a moral category. In W. J. Morgan (Ed.), Ethics in Sport (pp. 141-152). Human Kinetics.

Koç, Y. (2017). Beden eğitimi dersinde sportmenlik davranışı kazandırmaya yönelik uygulama önerisi: Küçüklerin oyununda centilmenliğin yapılandırılması (KOCY) [A practice proposal for promoting sportsmanship behavior in physical education course: Constructing Sportsmanship in Juniors' Games (CSJG)]. Erzincan University Journal of Education Faculty, 4(3), 125-129.

Koc, Y., \& Karabudak, A. A. T. (2017). The relationship between sportsmanship level of secondary school students and their success regarding the religious culture and knowledge of ethics course. Educational Research and Reviews, 12(16), 754-761. https://doi.org/10.5897/ERR2017.3316

Koç, Y., \& Yeniçeri, S. (2017). An investigation of the relationship between sportsmanship behavior of students in physical education course and their respect level. Journal of Education and Training Studies, 5(8), 114-122. https://doi.org/10.11114/jets.v5i8.2477

Lodl, K. (2005). Developing a game plan for good sportsmanship. New Directions for Youth Development, 127-134. https://doi.org/10.1002/yd.147 
Lumpkin, A., Stoll, S. K., \& Beller, J. M. (2002). Sport ethics: Applications for fair play. Boston, MA: McGraw-Hill.

Martens, R. (2004). Successful coaching (3rd ed.). Champaign, IL: Human Kinetics.

MEB. (2013). Beden eğitimi ve spor dersi ögretim programı uygulama kılavuzu (ortaokul 5-8. sinıflar). Ankara.

Nucci, C., \& Young-Shim, K. (2005). Improving Socialization through Sport: An Analytic Review of Literature on Aggression and Sportsmanship. Physical Educator, 62(3), 123-129.

Patrick, C. A., Ward, P., \& Crouch, D. W. (1998). Effects of holding students accountable for social behaviors during volleyball games in elementary physical education. Journal of Teaching in Physical Education, 17, 143-156. https://doi.org/10.1123/jtpe.17.2.143

Pehlivan, Z. (2004). Fair-play kavramının geliştirilmesinde okul sporunun yeri ve önemi. SPORMETRE Beden Eğitimi ve Spor Bilimleri Dergisi, II(2), 49-53. https://doi.org/10.1501/Sporm_0000000028

Perry, J. L., Clough, P. J., \& Crust, L. (2013). Psychological approaches to enhancing fair play. Athletic Insight, 15(2), 197. Retrieved June 19, 2013, from http://www.athleticinsight.com/Vol5Iss2/Feature.htm

Power, F. C., \& Sheehan, K. K. (2014). Moral and character education through sports. In L. Nucci, T. Krettenauer, \& D. Narváez (Eds.), Handbook of moral and character education (2nd ed., pp. 488-506). Routledge.

Rosa, B. A. (2015). Ethics in Sport-Guidelines for Teachers. Mafra: Luso-Illyrian Institude for Human Development (iLIDH).

Shields, D. L., \& Bredemeier, B. J. L. (1995). Character development and physical activity. Champaign, IL: Human Kinetics.

Siedentop, D., Hastie, P. A., \& van der Mars, H. (2004). Complete guide to sport education (2nd ed.). Champaign, IL: Human Kinetics.

Thompson, J. (1995). Positive coaching: Building character and self-esteem through sports. Portola Valley, CA: Warde Publishing.

Vallerand, R. J., Briere, N. M., Blanchard, C. M., \& Provencher, P. J. (1997). Development and validation of the multidimensional sportspersonship orientations scale. Journal of Sport \& Exercise Psychology, 19(2), 197-206. https://doi.org/10.1123/jsep.19.2.197

Wells, M. S., Ellis, G. D., Paisley, K., \& Arthur-Banning, S. G. (2005). Development and evaluation of a program to promote sportsmanship in youth sports. Journal of Park \& Recreation Administration, 23(1), $1-17$.

Wells, M., Arthur-Banning, S. G., Paisley, K., Ellis, G. D., Roark, M. F., \& Fisher, K. (2008). Good (youth) sports: Using benefits-based programming to Increase Sportsmanship. Journal of Park \& Recreation Administration, 26(1), 1-21.

Yapan, H. T. (2007). Spor ahlakı. Gaziantep: Merkez Ofset.

Yıldıran, İ. (2005). Fair play eğitiminde beden eğitiminin rolü. Gazi Beden Eğitimi ve Spor Bilimleri Dergisi, 5(1), 3-16.

Yıldırım, A., \& Şimşek, H. (2013). Sosyal bilimlerde nitel araştırma yöntemleri (Geliştirilmiş Dokuzuncu Baskı). Ankara: Seçkin.

\section{Note}

Note 1 . This study was orally presented at the $14^{\text {th }}$ International Sport Sciences Congress (November 1, 2016), Antalya/Turkey.

\section{Copyrights}

Copyright for this article is retained by the author(s), with first publication rights granted to the journal.

This is an open-access article distributed under the terms and conditions of the Creative Commons Attribution license (http://creativecommons.org/licenses/by/4.0/). 